\title{
Exploring a Tiriti-based superdiversity paradigm within early childhood care and education in Aotearoa New Zealand
}

Contemporary Issues in Early Childhood

(C) The Author(s) 2020 Article reuse guidelines: sagepub.com/journals-permissions DOI: | $0.1|77 /| 463949|2097| 376$ journals.sagepub.com/home/cie

(SAGE

\section{Angel Chan 1}

The University of Auckland, New Zealand

\section{Jenny Ritchie}

Te Herenga Waka Victoria University of Wellington, New Zealand

\begin{abstract}
This article reports findings from a study that used a process of document analysis to examine early childhood care and education responses to increasing superdiversity in the 'bicultural' legislative context of Aotearoa New Zealand. The New Zealand Education Review Office has described both Indigenous Māori children and 'children of migrants and refugees' as 'vulnerable' and 'priority learners'. This article uses the lenses of Te Tiriti o Waitangi (Indigenous rights) and Steven Vertovec's superdiversity approach to examine the implications of representations of the Indigenous Māori and the settler population in early childhood care and education in Aotearoa New Zealand. It further applies Sara Ahmed's diversity work on a phenomenology of whiteness to scrutinise the New Zealand government's commitments to supporting its nation's 'priority learners'.
\end{abstract}

\section{Keywords}

early childhood care and education, phenomenology of whiteness, priority learners, superdiversity, Te Tiriti o Waitangi

In 2013, the Royal Society of New Zealand (2013: 1) reported that the country was 'now home to 160 different languages' and used the term 'superdiverse' to describe the demographic landscape of Aotearoa New Zealand (hereafter Aotearoa). ${ }^{1}$ Recent statistics highlight that $27.4 \%$ of the 
nation's total population and 39.1\% of those living in the largest city in Aotearoa, Auckland, were born outside of the country (Auckland Council, 2014; Statistics New Zealand, 2019). Statistics New Zealand (2019) uses several broad ethnic groups to categorise the population: European (70.2\%), Māori (16.5\%), Asian (15.1\%), Pacific peoples $(8.1 \%)$ and Middle Eastern/Latin American/African (1.5\%). This superdiversity situation is even more evident in the country's early childhood care and education (ECCE) settings. In 2018, the historically dominant ethnicity (European/Pākehā) accounted for only $48 \%$ of ECCE enrolments, with the remainder comprising Māori, Pacific, Asian and Other ethnic groups (Education Counts, 2018). ${ }^{2}$

Vertovec's $(2007,2019)$ superdiversity approach considers that this globally unprecedented phenomenon can no longer be adequately explained and addressed by conventional perspectives of diversity and multiculturalism via 'simple ethnicity-focused approaches' to understanding and working with diverse communities (Vertovec, 2007: 1039). Instead, the notion of superdiversity focuses on newly emergent migration-driven social issues, inequalities, prejudices and exclusions, which may not previously have been considered in social policies (Vertovec, 2007, 2019). In light of these concerns, this study aimed to explore how the ECCE sector in Aotearoa has responded with regard to supporting migrant children and families.

In this article, we discuss the complex concerns of inequality issues emerging from a superdiverse demographic landscape within a Tiriti o Waitangi-based 'bicultural' Aotearoa. ${ }^{3}$ This particular superdiversity environment 'is rendered more complex because it is proceeding in an embedded and rapidly evolving bicultural legislative system' (Royal Society of New Zealand, 2013: 2). We argue that viewing migration-driven social inequality issues through a superdiversity lens alone is insufficient in Aotearoa. Instead, we locate this lens within a wider Tiriti-based framework (Came et al., 2020) in order to conceptualise the complex relations between the treaty 'partners': the Indigenous Māori and those who are more recent arrivals in this country. Lastly, aspects of Ahmed's (2007a, 2012) work on diversity and whiteness are used to make sense of the challenges to educational responses to the current superdiversity situation and related inequality issues in ECCE settings in Aotearoa.

\section{Complex relationships: Te Tiriti o Waitangi and superdiversity in Aotearoa}

In this section, we provide the background to key constructs related to our focus in this article - the implications of a superdiversity lens in Tiriti-based Aotearoa - beginning with Te Tiriti o Waitangi.

\section{Te Tiriti o Waitangi}

Te Tiriti o Waitangi is the 1840 treaty that legitimised British settlement and led to the colonisation of Aotearoa via the assumption of British sovereignty, whereby majoritarian and white supremacist policies disregarded the rights that had been promised to Māori within the Māori-language version of this treaty, which was signed by over 500 Māori chiefs and Captain William Hobson on behalf of the British Crown (Orange, 1987; Ritchie, 1992; Walker, 2004). In Article One, Māori allowed $k \bar{a}$ wanatanga ('governance') by the British Crown (and then, from 1852, the settler government). It implies that good governance would entail upholding the remaining articles. Article Two references Māori self-determination over lands and taonga (aspects highly valued by Māori such as Te Reo Māori, the Māori language). Article Three requires that Māori be treated as equal citizens as Māori and implies equitable opportunities, and a verbal fourth article gave equal standing for Māori spiritual beliefs (Berghan et al., 2017). ${ }^{5}$ Innumerable and relentless treaty breaches resulted in inestimable damage and trauma across multiple generations of Māori whānau 
('extended families'), hapu ('subtribes') and iwi ('tribes'), due to the extensive loss of lands, resources, languages and cultural knowledges (see Marr, 1997; Orange, 1987; Pihama et al., 2014; Waitangi Tribunal, 1986, 2014; Walker, 2004).

From a Tiriti-based perspective, there are two broad parties to the treaty. The first is Māori, also known as tangata whenua ('people of the land') and comprising many different hapu and $i w i$. The second grouping, termed tangata tiriti ('people of the treaty') (Durie, cited in King, 2003: 191), includes all those who do not have Māori ancestry. The residence in Aotearoa of the latter party was legitimised initially by Te Tiriti o Waitangi and subsequent government migration policies. This framing, which recognises Māori as the original people of Aotearoa, is often termed a 'bicultural' model. 'Biculturalism' can be critiqued for various reasons, including its inadequacy in relation to acknowledging the power differentials between Māori and the settler-dominated government (O’Sullivan, 2007), and for the focus on Māori and Pākehā, excluding the many citizens with diverse ethnicities. The term 'bicultural' is also misleading when applied at the individual level, since the diverse cultural and linguistic backgrounds of many citizens may not necessarily include Māori and/or English. For these reasons, we advocate a Tiriti-based rather than 'bicultural' framing.

As a result of ongoing Māori activism, 135 years on from the signing of the treaty, in 1975, the government finally acknowledged the treaty. In 1987, Te Reo Māori was declared an official language (New Zealand Parliament, 1987) and, in 1989, the Education Act recognised the Treaty of Waitangi. ${ }^{6}$ The commitment of the education sector in supporting Te Tiriti o Waitangi and diversity is reflected in Section 1AA3 of this Act, which states that the objectives for both early childhood and compulsory education are

to instil in each child and young person an appreciation of the importance of the following:

(i) the inclusion within society of different groups and persons with different personal characteristics;

(ii) the diversity of society;

(iii) cultural knowledge, identity, and the different official languages;

(iv) the Treaty of Waitangi and te reo Māori. (New Zealand Parliament, 1989)

We address these yet-to-be-fully-realised commitments in this article.

\section{Superdiversity and its challenges: white-dominant and 'biculturalism'}

We argue that consideration of a superdiversity approach based on recognition of Te Tiriti o Waitangi, thus affirming the first-nation status of the Indigenous Māori, has the potential to strengthen equitable and inclusive policies and practice in Aotearoa. Vertovec's (2019: 126) superdiversity approach calls for an examination of the implications of 'new migration patterns' in relation to social issues, particularly 'new hierarchical social positions, statuses or stratifications'. This deepens understandings and responses beyond the usual considerations of ethnicities, cultures and languages, thus diversifying traditional understandings of diversity.

Superdiversity considerations include differential migration patterns (e.g. permanent settlement in the host country, short-term migration for the purposes of work or study, or transnational migration involving frequent commuting between the host and home countries) and variable migration statuses (such as involuntary migrants with a refugee background or voluntary migrants whose 
backgrounds have fulfilled the criteria of the host countries). Permanent migration and full integration are no longer the only approaches adopted by 21 st-century migrants. Instead, most migrants nowadays maintain close contact with their family and community remaining in their home countries, and some transnational migrants adopt a lifestyle that involves spending time living in both their home and host countries (Spoonley and Bedford, 2012; Vertovec, 2007). Transnational activities involving intercultural exchanges have also given rise to an unprecedented level of pluralism: plural identities, citizenships, languages and cultural repertoires (Ndhlovu, 2016). Such complexities pose challenges for conservative and monocultural individuals and institutions in acknowledging and responding to social changes with equitable policies.

In her work, Ahmed (2007a: 156) uses the notions of 'likeness' and 'habit' to explain how institutions privilege ideas and practices that align with their (white) ways of being and doing, thereby constructing and perpetuating 'whiteness as a habit, as second nature', and maintaining the status quo. She describes 'diversity work as willful work', challenging 'institutional whiteness' (Ahmed, 2012: 2) and the 'will' of institutions in responding to diversity. She highlights that migrants are expected to 'align their particular will with the general will' before they are socially accepted (Ahmed, 2012: 7), and that 'the familial is after all about the familiar' (Ahmed, 2007a: 155).

Institutional expectations are implicated in perpetuating social inequalities. For example, most contemporary migrant families choose to maintain their heritage, meaning that their children have to acquire at least two sets of cultural patterns and languages, which can create pressures and tensions. On engaging with educational settings, these children and their parents may take longer than local families to understand both the covert and overt expectations, particularly when there are language barriers (Chan, 2018). Research has shown that some teachers hold stereotypical views of migrant children and parents who use English as an additional language, assuming that these parents are disinterested in their children's learning and therefore provide their children with fewer resources and simpler learning experiences (Banks, 2002; Huss-Keeler, 1997). Transnational migrants may be marginalised by some members of the host countries, who perceive them to be disloyal in their reluctance to integrate fully (Goldberg, 2002). Moreover, families with a refugee background may have fewer financial resources with which to navigate the host country, and recent studies have identified specific pedagogical considerations for supporting these families' constructions of identity and sense of belonging (Mitchell and Bateman, 2018).

Several scholars have discussed multiculturalism, cultural diversity and superdiversity within the 'bicultural' Aotearoa context, highlighting a range of complexities in relation to the original treaty partnership between Māori and the British Crown, and the increasing diversity of migrants due to recent migration policies (Chan, 2009; Bartley and Spoonley, 2005; May, 2004; Spoonley, 2015; Ward and Liu, 2012). Ward and Liu (2012: 61) acknowledge that 'historical and sociopolitical factors' have contributed to tensions in relationships between Māori and 'the country's new settlers'. This lack of relationship-building has been exacerbated in that the government's migration policies and procedures have not been generated or conducted in consultation with Māori. 'Biculturalism', as recognising Māori first-nation status and treaty rights, and 'multiculturalism' are often considered as mutually exclusive in Aotearoa, and managing them well is considered a major challenge and a priority in promoting harmonious ethnic relations (Bartley and Spoonley, 2005; Ward and Liu, 2012).

Due to the ongoing legacy of colonisation, Māori continue to be over-represented negatively in social and economic indicators such as imprisonment rates, home ownership, poverty and life expectancy (Ministry of Health, 2018; Walters, 2018). However, many citizens and, in particular, recent arrivals to the country may have a minimal understanding of the history of colonisation and 
its impacts on Māori. A lack of relationships between ethnic groups may contribute to negative perceptions and attitudes. Māori and migrants may be positioned as competing for limited economic resources and, for Māori, the presence of 160 other languages and diverse ethnicities may be seen as threatening the potential to sustain the Māori language and culture. Whilst treaty commitments ostensibly inform 'bicultural' policies, the lack of a clearly articulated national cultural diversity policy may mean that those with ethnicities other than Māori and Pākehā may feel that their concerns are largely ignored (Bartley and Spoonley, 2005). Underpinned by the theoretical lens of Ahmed's work and informed by the complex relations between the current superdiversity phenomenon in Aotearoa and its Tiriti-based obligations, this study set out to investigate and critically analyse the nation's commitment in responding equitably to children and families with superdiverse backgrounds in ECCE settings.

\section{The Education Review Office's evaluation of ECCE services}

When the Education Review Office (ERO) evaluates individual ECCE services, it is currently guided by a document called He Pou Tätaki (Education Review Office, 2013). ${ }^{7}$ Both He Pou Tātaki and the New Zealand early childhood curriculum - Te Whāriki: He Whāriki Mātauranga mō ngā Mokopuna o Aotearoa: Early Childhood Curriculum (Ministry of Education, 1996, 2017) are underpinned and guided by a Māori philosophical framework. Detailed lists of indicators and evaluative questions are provided (Education Review Office, 2013: 23-41). For example, services are encouraged to review their effectiveness with regard to:

- Supporting Māori children to achieve success as Māori

- Supporting Pacific children to achieve success

- Responding to the interests, strengths and capabilities of diverse groups of children who attend the service and supporting them to achieve success

- [Promoting] partnerships with parents and whānau. (Education Review Office, 2013: 36)

A more recent ERO document, published after the data gathering and analysis in this study, is Te Ara Poutama: Indicators of quality for early childhood education: What matters most. This document places an expectation that kaiako ('teachers') 'purposefully seek the views of children, parents and whānau' so that the local curriculum responds to 'diverse languages, cultures and identities', and that kaiako will also 'seek ways to maintain children's connections to, and fluency in their home language/s and cultural identities’ (Education Review Office, 2020: 17).

\section{Research method}

In order to explore how the ECCE sector in Aotearoa is responding to superdiversity, a process of document analysis (Ahmed, 2007b; Bowen, 2009; Shaw et al., 2004) was used to examine a range of macro- and micro-documents collected via the Internet. Since reference to 'superdiversity' is rare in educational research and literature in Aotearoa, specific attention was given to references made to diversity, migrants and migration-related issues during the data collection phase. While, at the macro level, mandatory institutional documents proclaim the nation's commitments to certain values and beliefs (Ahmed, 2007b; Shaw et al., 2004), at the micro level, it is common for ECCE 
centres in Aotearoa to express their aspired values and practices in philosophy statements, which are often visible on their websites.

\section{Data gathering and selection criteria}

It is to be expected that the macro-policy arena significantly shapes and influences how microdocuments, such as centres' philosophy statements and ERO reports, are written. The intention of examining philosophy statements was to find out whether/how the centres claim to embrace notions related to (super)diversity, whereas the aim of reviewing the ERO reports on individual centres was to gain insights into how the aspirational and commitment statements might have been translated into practice and thus noted by the ERO. The macro-documents that were examined were Te Whāriki (Ministry of Education, 1996, 2017) and He Pou Tätaki (Education Review Office, 2013). The micro-documents comprised the individual philosophies of 92 ECCE centres and their last two ERO evaluative reports.

Superdiversity is largely an urban phenomenon and Auckland is now 'one of the most diverse cities in the world' (Royal Society of New Zealand, 2013: 2). Statistics further show that Asian and Middle Eastern/Latin American/African ethnic groups live predominately in the Auckland region of the North Island, whereas the South Island regions have a much higher proportion of Europeans/ Pākehā (Statistics New Zealand, 2018). The researchers selected ECCE centres across Aotearoa which had an enrolment of fewer than $50 \%$ European/Pākehā children. ${ }^{8}$ These statistics are available in each ECCE centre's ERO report. Based on this knowledge and the demographic criterion, 53 centres in Auckland, 20 centres in the remaining North Island, and 19 centres in the South Island were identified.

Once the centres had been selected, the researchers visited each centre's website to collect its philosophy statement. Some of these statements were downloadable while some had to be converted into a Word document to be stored electronically. At times, the researchers also took screenshots of the statements, which were often accompanied by images that visualised the centres' commitments. For example, it is common for a centre to highlight its commitments to biculturalism and embracing diversity, both of which are expectations of the Ministry of Education and ERO, by including pictures of children and adults with a range of ethnic backgrounds interacting joyfully. Visual 'images of "colourful" happy faces' (Ahmed, 2007b: 604) may be seen to be employed as a marketing strategy to entice families with ethnically diverse backgrounds by signalling that their child will be included by other children and cared for by teachers who share the same language and culture.

\section{Data analysis process and a new thread of investigation}

All of the documents were imported into the NVivo software programme for analysis. The nodes were generated using the 'Word Tree' function of the programme and keywords/issues commonly associated with the study of migration, culture and diversity. An Excel spreadsheet was also created to gather statistics of how often the nodes were mentioned in the micro-documents. Once the data had been processed and the spreadsheet completed, the first author felt that the superdiversity approach and her knowledge of migration and diversity study seemed to be inadequate to interpret the initial findings in relation to Aotearoa's Tiriti-based/bicultural context. This led to conversations with the second author. The authors then decided to start a new thread of analysis, which sparked the idea of reporting a specific aspect of the findings presented in this article: the complex relations between tangata whenua Māori and diverse migrants in Aotearoa, and the associated inequality concerns. Hence, only data related to (super)diversity and biculturalism or Te Tiriti o Waitangi is considered in this article. Since the ERO's evaluation reports of ECCE centres are 
publicly available on the ERO's website, ${ }^{9}$ and all of the philosophy statements are also accessible through the centres' websites, for ethical reasons we do not use any direct quotes from the microdocuments, in order to protect the identities of the centres.

\section{Findings and discussion}

Here we discuss representation of commitments to Te Tiriti o Waitangi and (super)diversity, and their complexities in Aotearoa, informed by critical Tiriti policy analysis (Came et al., 2020), key ideas from Vertovec's $(2007,2019)$ superdiversity approach, and the phenomenology of whiteness theorised by Ahmed (2007a, 2012).

\section{Macro-commitments: Te Tiriti o Waitangi and (super)diversity}

The original Te Whāriki (Ministry of Education, 1996) was not only progressive in its sociocultural and holistically integrated framing; it was also the first 'bicultural' curriculum for Aotearoa. This was demonstrated in its recognition of Te Tiriti and related expectations, as exemplified in the statement that 'all children should be given the opportunity to develop knowledge and an understanding of the cultural heritages of both partners to Te Tiriti o Waitangi', and this 'question for reflection': 'In what ways do the environment and programme reflect the values embodied in Te Tiriti, and what impact does this have on adults and children?' (Ministry of Education, 1996: 9, 56).

The 2017 Te Whäriki recognises both treaty versions as the founding documents of the nation, diminishing previous emphasis on Te Tiriti o Waitangi, the document signed by the Māori chiefs. It goes on to recognise the relationship between Māori and Pākehā, stating that 'central to this relationship was a commitment to live together in a spirit of partnership and the acceptance of obligations for participation and protection' (Ministry of Education, 2017: 3). Instead of attending to the obligations contained within the specific articles of Te Tiriti, as per a Tiriti-informed framework (Came et al., 2020), this statement references the oft-cited but ambiguous three 'Ps' of 'partnership, protection and participation' (Royal Commission on Social Policy, 1987). It goes on to state:

New Zealand is increasingly multicultural. Te Tiriti/the Treaty is seen to be inclusive of all immigrants to New Zealand, whose welcome comes in the context of this partnership. Those working in early childhood education respond to the changing demographic landscape by valuing and supporting the different cultures represented in their settings. (Ministry of Education, 2017: 3)

It further includes a strong thread of Māori worldviews and related expectations throughout, and highlights the obligation of ECCE settings with regard to achieving equitable outcomes for Māori children and children with diverse backgrounds. It includes a single page focused on the responsibilities of teachers, including the expectations that they be

- culturally competent: developing increasing proficiency in the use of te reo and tikanga Māori [Māori cultural values and practices] and able to form responsive and reciprocal relationships with tangata whenua

- able to support the cultural and linguistic diversity of all children as part of promoting an inclusive environment. (Ministry of Education, 2017: 59) 
According to He Pou Tãtaki: 'Te Tiriti o Waitangi informs the development and implementation of all policies and procedures in ERO, including its education evaluation approaches' (Education Review Office, 2013: 5). Since 2009, the government's education strategy, Ka Hikitia (Ministry of Education, 2009, 2013), has focused on the need for teachers to ensure educational success for Māori children 'as Māori' via the recognition and affirmation of 'being Māori' as a source of potential. The strategy has aimed to shift discourse from the historical white supremacist deficit view of anyone who does not share the same 'likeness' with the dominant group and who practises 'unfamiliar' beliefs as being 'the problem' (Ahmed, 2007a) to one that positions Māori language, culture and identity to be a source of strength and connection for teacher engagement with Māori children and their families. He Pou Tătaki also states that the government has identified a group of 'priority learners' who are the 'most vulnerable children', which includes 'Māori, Pacific, those from low income families, and children with diverse needs' (Education Review Office, 2013: 8). This includes children with 'special education needs or special abilities, children from low income families, children who speak English as an additional language (EAL), and children of migrants and refugees' (9), and requires teachers to provide 'additional supports to help them [priority learners] achieve equitable outcomes' (8). Whilst this notion of 'priority learners' requires pedagogical recognition of 'diversity', it is simultaneously problematic in that labels such as 'vulnerable' and 'priority learners' may serve as code that reinforces stereotypical othering and deficit views. It is thus important that teachers move beyond the rhetoric of such institutional discourses to avoid reinscribing deficit thinking and instead see children's cultural and other specificities as assets which serve as the fundamental basis for building understandings and relationships.

\section{Micro-commitments}

Since such key documents reflect a commitment to the treaty, it is unsurprising that treaty and/or bicultural practices are stated as an expectation in almost all (96\%) of the ERO centre reports examined. On the other hand, whilst 'diversity' was mentioned in ECCE centres' philosophy statements and ERO reports, almost no reference has been made to migrant families or migrationrelated issues, even though $\mathrm{He}$ Pou Tätaki identifies that children of migrants and refugees require 'additional supports' from teachers (Education Review Office, 2013: 8). Table 1 provides a statistical overview of the micro-attention given to terms related to Te Tiriti o Waitangi/biculturalism and (super)diversity, with analysis following.

Attention given to biculturalism and Te Tiriti o Waitangi/the Treaty of Waitangi. In its centre evaluative reports, the ERO either acknowledges a centre's bicultural practices positively, such as stating that the programme provides opportunities for children to learn about the bicultural heritage of Aotearoa, or as a priority to be strengthened - by integrating bicultural perspectives into the centre's philosophy statement, for example. Nonetheless, only $39 \%$ of the centres' websites featured a commitment to the treaty and/or biculturalism. This was mostly through their philosophy statements, which might include a whakataukī (Māori 'proverb') or other Māori phrases. ${ }^{10}$ Regional differences were noticeable. High proportions of Māori appear in the regions of Gisborne (48.9\%) and Northland (32.4\%) in the North Island (Statistics New Zealand, 2014). The ECCE centres selected from these regions accordingly have a high enrolment of Māori children, and therefore more Māori content on their websites. A lower percentage of centres in Southland, where few Māori reside, showcased their commitments to biculturalism and/or the treaty, suggesting an outof-sight, out-of-mind syndrome.

We further analysed phrases from the websites using a Te Tiriti article framework (Came et al., 2020), which involved the four articles described above. With regard to the Article Two 
Table I. Comparative percentages across micro-documents.

\begin{tabular}{lclcc}
\hline Mentions of & Auckland & $\begin{array}{l}\text { North Island } \\
\text { (excluding Auckland) }\end{array}$ & South Island & Total \\
\hline $\begin{array}{l}\text { Biculturalism/treaty/Tiriti on ECCE } \\
\text { centres' websites }\end{array}$ & $17 / 53(32 \%)$ & $14 / 20(70 \%)$ & $5 / 19(26 \%)$ & $36 / 92(39 \%)$ \\
$\begin{array}{l}\text { Biculturalism/treaty/Tiriti in ECCE } \\
\text { centres' individual ERO reports }\end{array}$ & $50 / 53(94 \%)$ & $19 / 20(95 \%)$ & $19 / 19(100 \%)$ & $88 / 92(96 \%)$ \\
$\begin{array}{l}\text { Diversity (in a broad sense) on ECCE } \\
\text { centres' websites }\end{array}$ & $48 / 53(91 \%)$ & $7 / 20(35 \%)$ & $11 / 19(58 \%)$ & $66 / 92(72 \%)$ \\
$\begin{array}{l}\text { Diversity (in a broad sense) in ECCE } \\
\text { centres' individual ERO reports }\end{array}$ & $42 / 53(79 \%)$ & $13 / 20(65 \%)$ & $13 / 19(68 \%)$ & $68 / 92(74 \%)$ \\
$\begin{array}{l}\text { Im/migrants or im/migration on ECCE } \\
\text { centres' websites }\end{array}$ & $1 / 53(1.9 \%)$ & $0 / 20(0 \%)$ & $0 / 19(0 \%)$ & $1 / 92(1 \%)$ \\
$\begin{array}{l}\text { Im/migrants or im/migration in ECCE } \\
\text { centres' individual ERO reports }\end{array}$ & $1 / 53(1.9 \%)$ & $0 / 20(0 \%)$ & $0 / 19(0 \%)$ & $1 / 92(1 \%)$ \\
\hline
\end{tabular}

commitment to self-determination, in the centres' philosophy statements, although there were no specific examples affirming a commitment to Māori self-determination, one centre recognised the position of Māori as tangata whenua. Many centres made a general statement that they applied or supported the Treaty of Waitangi, and one centre claimed that it was working to develop a 'bicultural relationship' as per the treaty. One ERO report noted that a programme had benefited from iwi support and another advised a centre to enhance its work further by developing connections to local $i w i$. In respect to upholding taonga, several centres recognised the Māori language to be a unique or living language or referred to te ao Māori (the Māori 'worldviews') and Māori children's identities and culture. In the ERO reports, there are frequent references to teachers and programmes featuring the Māori language and perspectives, waiata (Māori 'songs') and tikanga Māori. One ERO report noted that Māori children's identities, language and culture were supported. Also mentioned are visits to marae (Māori 'meeting places'). In terms of citizenship rights, as per Article Three, one centre made reference to providing support and encouragement to Māori children, reiterating Ka Hikitia's (Ministry of Education, 2013) position that they should enjoy success as Māori. The centres did not appear to state any commitments to recognising Māori spiritual beliefs, as per Article Four, but one ERO report noted a centre's use of karakia (spiritual recitation).

Attention given to (super)diversity. The figures reported in Table 1 indicate how often the notion of diversity is mentioned in a very broad sense because it is common for centres and the ERO to use the term 'diversity' as a generic entity. For example, 'diversity is valued and celebrated' and 'the centre serves a diverse community' are typical statements in centres' ERO reports. A conventional understanding of diversity is also often demonstrated in the micro-documents of the selected ECCE centres. For example, diverse ethnicities, identities, languages and cultures are typically referred to (but often lumped into one statement), and diverse abilities and educational needs are also often included. Broad evaluative statements in He Pou Tätaki - such as 'how approaches to teaching and learning are responsive to diversity' and 'responding to the interests, strengths and capabilities of diverse groups of children' (Education Review Office, 2013: 21,36) - are likely to have contributed to the ERO's and ECCE centres' generic conceptualisation of 'diversity'.

Since the notion of superdiversity focuses on migration-related issues, the researchers purposely looked for any mention of the words 'immigrant'/'migrant', 'refugees', 'migration', and so on. The term 'superdiversity', as expected, was not found anywhere, whilst 'immigrant' was found on only one centre's website (out of 92) and in one of the ERO reports for that particular centre. None of 
the other migration-related words appeared in the ERO reports, even though the need for support for children of migrants and refugees is mentioned in He Pou Tätaki (Education Review Office, 2013). The notion of 'priority learners' in He Pou Tātaki reflects a commitment to respond equitably to diversity but, while $74 \%$ of the ERO reports examined referred broadly to diverse abilities and the educational needs of children, the low (1.9\%) mention of migrant and migrant-focused concerns has significant implications.

The concept of superdiversity emphasises complex and multilayered migration variables and resulting migration-driven inequality issues (Vertovec, 2007, 2019). We argue that, unless issues related to migrant families are highlighted in ERO reports, teachers will remain unlikely to pay attention to the needs of migrant children and their families. Compared to the way in which biculturalism is highlighted in many ERO reports as an area to be improved or commended (as explained in the earlier section), this lack of attention from the ERO with respect to supporting children with migrant and refugee backgrounds suggests that these groups have not actually been treated with much priority. We believe that the uneven attention given to different groups of 'priority learners' may be, in part, due to perceived tensions between 'biculturalism' and 'multiculturalism' or superdiversity, and a lack of clear directives in policies regarding the two frameworks.

\section{'Biculturalism' and/or superdiversity: challenges and possibilities}

In our work with both pre-service and in-service teachers over many years, we have often encountered the challenge that to recognise Māori as tangata whenua is perceived as unfair, unnecessary or irrelevant 'special treatment', particularly when education settings comprise a wide range of ethnicities and nationalities. However, our position is that to ignore the commitments made to Māori in Te Tiriti o Waitangi and the legacy of the ongoing impacts of colonisation on Māori wellbeing, language and belief systems, as well as the clear expectations from the Ministry of Education (1996, 2017) and ERO (2013), is clearly not an ethical pathway forward.

Taking an analytical approach founded in the work of Ahmed, we expose and contest the potential for perpetuating historical patterns of white dominance and the ubiquity of white hegemony. Without this exposure and critique, the likelihood is that patterns of dominance in power relations will be reinscribed. This has the potential to reinforce whiteness into a 'habit' (Ahmed, 2007a), recolonising Māori and perpetuating the ignoring of the specificities of attentiveness required in response to the multilayered complexities of migration-related superdiversity issues related to differentials in migration status, income, ethnic and linguistic complexities, religion, lack of extended family support, and so forth. Yet to recognise and affirm differences is often perceived 'as assertive, as rocking the boat' (Ahmed, 2012: 13), and not aligned with the dominant collective habit. Ahmed (2012: 12) warns that 'a habit is a continuation of willing what no longer needs to be willed'. Without a will from institutions to interrogate, historical inequities are likely to be exacerbated and, for recent migrants, discrimination is likely to be perpetuated, and their needs and contributions ignored. We wonder how educators might proactively challenge this phenomenology of whiteness and break these habits of whiteness (Ahmed, 2007a, 2012).

Te Tiriti o Waitangi has been described as a treaty of 'allowance' (Grace, 2000: 24), which, from a Māori perspective, marked the forging of a perpetual relationship of respect, understanding and trust, even though Māori have consequently endured ongoing discrimination and marginalisation in their own land (Walker, 2004). Te Tiriti can be seen as applying to both Māori (tangata whenua) and all subsequent settlers (tangata tiriti) (Durie, cited in King, 2003: 191). In this view, whilst the Te Tiriti obligations of the rights of Māori are to be upheld, attention to the aspirations and needs of the settler population, including both Pākehā and more recent settlers, should also be honoured and catered for. The notion of superdiversity emphasises considerations of the complex heterogeneous 
experiences of migrants, and biases and inequalities driven by recent migration patterns (Vertovec, 2007, 2019). We therefore argue that considerations of social justice and injustices derived from assumptions of white superiority and majoritarianism apply to both iwi Māori and recent migrants, particularly since many recent migrants are from previously colonised countries. It might also be considered problematic that, under the Tiriti-based framework of tangata whenua-tangata tiriti, local Pākehā and historically 'colonised' migrant populations from, for example, India and African countries are grouped together as tangata tiriti, potentially 'masking the marginalization of ethnoculturally diverse populations, and of the wider structures of racism and disadvantage that affect them as well' (Simon-Kumar, 2019). Additionally, while migration-driven inequalities are a key concern from a superdiversity lens, the rights of Māori endowed by Te Tiriti o Waitangi absolutely must also be honoured. We consider that attention to Te Tiriti commitments and superdiversity issues need not be mutually exclusive with regard to education policy and practice. Rather, when applied together, they open up spaces in which to create new possibilities for understanding and learning.

\section{Conclusion}

The findings from this study illustrate and problematise the complex relations between Indigenous Māori and migrants within the 'bicultural' legislative and policy environment of Aotearoa. They suggest the importance of analysing and responding to the discrimination and inequalities experienced by Indigenous Māori and migrants in light of both Te Tiriti o Waitangi and a superdiversity lens, as well as exercising a will to break the habit of whiteness. In Our code, our standards, the Education Council of Aotearoa states:

Te Tiriti o Waitangi is seen as a commitment under which Māori and all other New Zealanders may live together in the spirit of honourable relationships, with the promise to take the best possible care of each other. This requires the injustices caused by colonisation to be addressed and all New Zealanders to engage in creating a positive future that honours Te Tiriti o Waitangi. (Education Council, 2017: 4)

We argue that while continuing to address its commitment to Te Tiriti, the ERO also needs to start foregrounding the experiences of migrant families in their evaluative reports in order to draw ECCE centres' attention to transforming policies and practices to cater for the heterogeneous needs of migrant children, thereby also responding to their 'priority learner' status. Only when all citizens residing in Aotearoa are treated with respect with regard to their specific histories, heritages, languages and cultures can discrimination and inequalities be addressed. In a 2004 national report, the ERO highlighted:

There was a strong correlation between the quality of provision of te reo and tikanga Māori and the provision for the differing cultures of families contributing to services . . . it appears that attention to one had positive benefits for the other. (Education Review Office, 2004: 10)

It is disappointing that, after so many years, we are still unable to see this ERO finding being widely enacted. It is our hope that teachers will take up the challenges posed by honouring the specificities of both Māori and migrant histories, cultures, values, traditions and languages in their work, through building respectful, responsive and reciprocal relationships with children, extended families and communities, whereby they are able to effectively incorporate authentic representations of these within their local curriculum. 


\section{Funding}

The authors received no financial support for the research, authorship and/or publication of this article.

\section{ORCID iDs}

Angel Chan (iD https://orcid.org/0000-0001-5471-3522

Jenny Ritchie (iD) https://orcid.org/0000-0003-2934-6358

\section{Notes}

1. Aotearoa is a Māori name for New Zealand.

2. These are the broad ethnic categories used by the Ministry of Education.

3. 'Bicultural' refers to the two parties to Te Tiriti o Waitangi: first, Māori as the Indigenous people and, second, the original British settlers and all those who have migrated subsequently to Aotearoa. We prefer 'Tiriti-based framework' to the terms 'bicultural' and 'biculturalism' as the latter can be ambiguous and fail to recognise the first-nation status of Māori or the diversity of the settler population.

4. There are two versions of the treaty: Te Tiriti o Waitangi is the original treaty that was signed by the Māori chiefs and Crown, and the Treaty of Waitangi is the English-language version. There are significant differences between the versions. We privilege the Māori-language version as it was the one that was signed by the vast majority of chiefs. Whilst the New Zealand government acknowledges both versions, major commitments to Māori of self-determination are invisibilised when Tiriti/treaty discourse is subsumed within the English phrase 'Treaty of Waitangi'.

5. This fourth article was verbally articulated at the initial Waitangi signing, but has generally been disregarded by the Crown as it was not formally written down. However, equal recognition for Māori spiritual beliefs remains an important consideration and these are also a taonga that is highly valued by Māori, to be upheld under Article Two.

6. Since the two versions of the treaty are different, as stated earlier, we privilege the original treaty, referred to as Te Tiriti o Waitangi. However, the terms 'Treaty of Waitangi' and 'treaty' are often used generically.

7. The ERO is the government department that evaluates and reports on the care and education of children in early childhood and school settings in Aotearoa. It also publishes national reports on a range of education issues.

8. The data gathering was supported by two ECCE student teachers who were recipients of a scholarship funded by the University of Auckland.

9. See http://www.ero.govt.nz

10. For in-depth explanations of the key Māori constructs referred to in this article, including whakatauki and karakia (spiritual recitations, similar to prayers), see Rameka (2016).

\section{References}

Ahmed S (2007a) A phenomenology of whiteness. Feminist Theory 8(2): 149-168.

Ahmed S (2007b) 'You end up doing the document rather than doing the doing': Diversity, race equality and the politics of documentation. Ethnic and Racial Studies 30(4): 590-609.

Ahmed S (2012) Whiteness and the general will: Diversity work as willful work. philoSOPHIA 2(1): 1-20.

Auckland Council (2014) Auckland profile: Initial results from the 2013 Census. Available at: https://www. aucklandcouncil.govt.nz/plans-projects-policies-reports-bylaws/our-plans-strategies/auckland-plan/ about-the-auckland-plan/Documents/aucklandprofileinitialresults2013census201405.pdf

Banks JA (2002) An Introduction to Multicultural Education. Boston, MA: Allyn and Bacon.

Bartley A and Spoonley P (2005) Constructing a workable multiculturalism in a bicultural society. In: Belgrave M, Kawharu M and Williams D (eds) Waitangi Revisited: Perspectives on the Treaty of Waitangi. South Melbourne, VIC, Australia: Oxford University Press, pp. 136-148.

Berghan G, Came H, Coupe N, et al. (2017) Te Tiriti o Waitangi-based practice in health promotion. Auckland, New Zealand: STIR: Stop Institutional Racism. Available at: https://trc.org.nz/sites/trc.org. nz/files/ToW\%20practice\%20in\%20HP\%20online.pdf 
Bowen GA (2009) Document analysis as a qualitative research method. Qualitative Research Journal 9(2): $27-40$.

Came H, O'Sullivan D and McCreanor T (2020) Introducing critical Tiriti policy analysis through a retrospective review of the New Zealand Primary Health Care Strategy. Ethnicities 20(3): 434-456.

Chan A (2009) Critical multiculturalism: The challenge of multiculturalism within a New Zealand bicultural context - A Chinese perspective. International Journal of Equity and Innovation in Early Childhood 7(1): 29-40.

Chan A (2018) Transnational parenting practices of Chinese immigrant families in New Zealand. Contemporary Issues in Early Childhood 19(3): 219-230.

Education Council (2017) Our code, our standards: Code of professional responsibility and standards for the teaching profession. Wellington, New Zealand: Education Council. Available at: https://educationcouncil.org.nz/content/our-code-our-standards

Education Counts (2018) Annual ECE Census 2018: Fact Sheets. Available at: https://www.educationcounts. govt.nz/publications/series/annual-early-childhood-education-census/annual-ece-census-2018-factsheets

Education Review Office (2004) Catering for diversity in early childhood services. Wellington, New Zealand: Education Review Office.

Education Review Office (2013) He Pou Tātaki: How ERO reviews early childhood services. Wellington, New Zealand: Education Review Office. Available at: https://www.ero.govt.nz/publications/he-pou-tatakihow-ero-reviews-early-childhood-services/

Education Review Office (2020) Te Ara Poutama: Indicators of quality for early childhood education: What matters most. Wellington, New Zealand: Education Review Office. Available at: https://www.ero.govt. $\mathrm{nz} /$ publications/te-ara-poutama-indicators-of-quality-for-early-childhood-education-what-matters-most/

Goldberg DT (2002) The Racial State. Malden, MA: Blackwell.

Grace P (2000) The Treaty of Waitangi and the expression of culture in Aotearoa. In: Proceedings of the Treaty Conference 2000, Tamaki Makaurau/Auckland, 6-8 July 2000, pp. 24-27. Auckland, New Zealand: Treaty Conference 2000 Publication Group.

Huss-Keeler RL (1997) Teacher perception of ethnic and linguistic minority parental involvement and its relationships to children's language and literacy learning: A case study. Teaching and Teacher Education 13(2): 171-182.

King M (2003) The Penguin History of New Zealand. Auckland, New Zealand: Penguin.

Marr C (1997) Public works takings of Maori land, 1840-1981. Wellington, New Zealand: Waitangi Tribunal. Available at: https://www.waitangitribunal.govt.nz/assets/Documents/Publications/wt-theme-g-publicworks-takings-of-maori-land.pdf

May S (2004) Accommodating multiculturalism and biculturalism in Aotearoa/New Zealand: Implications for language policy. In: Spoonley P, Macpherson C and Pearson D (eds) Tangata, Tangata: The Changing Ethnic Contours of Aotearoa/New Zealand. Southbank, VIC, Australia: Thomson/Dunmore Press, pp. 247-264.

Ministry of Education (1996) Te Whāriki: He Whāriki Mātauranga mō ngā Mokopuna o Aotearoa: Early Childhood Curriculum. Wellington, New Zealand: Learning Media. Available at: https://education.govt. nz/assets/Documents/Early-Childhood/Te-Whariki-1996.pdf

Ministry of Education (2009) Ka Hikitia: Managing for success/Māori education strategy 2008-2012. Wellington, New Zealand: Ministry of Education. Available at: http://www.parliament.nz/resource/ennz/49SCMA_EVI_00DBSCH_INQ_9064_1_A14037/0449a92c3574c1e5b0f850ae1 fdb155b155fe3aa

Ministry of Education (2013) Ka Hikitia: Accelerating success 2013-2017: The Māori education strategy. Wellington, New Zealand: Ministry of Education. Available at: https://education.govt.nz/ministry-ofeducation/overall-strategies-and-policies/the-maori-education-strategy-ka-hikitia-accelerating-success-20132017/the-maori-education-strategy-ka-hikitia-accelerating-success-2013-2017/

Ministry of Education (2017) Te Whāriki: He Whāriki Mātauranga mō ngā Mokopuna o Aotearoa: Early Childhood Curriculum. Wellington, New Zealand: Ministry of Education. Available at: https://www. education.govt.nz/assets/Documents/Early-Childhood/Te-Whariki-Early-Childhood-Curriculum-ENGWeb.pdf 
Ministry of Health (2018) Socioeconomic indicators. Available at: https://www.health.govt.nz/our-work/ populations/maori-health/tatau-kahukura-maori-health-statistics/nga-awe-o-te-hauora-socioeconomicdeterminants-health/socioeconomic-indicators

Mitchell L and Bateman A (2018) Belonging and culturally nuanced communication in a refugee early childhood centre in Aotearoa New Zealand. Contemporary Issues in Early Childhood 19(4): 379-391.

Ndhlovu F (2016) A decolonial critique of diaspora identity theories and the notion of superdiversity. Diaspora Studies 9(1): 28-40.

New Zealand Parliament (1987) Maori Language Act 1987. Available at: http://www.legislation.govt.nz/act/ public/1987/0176/latest/DLM124116.html?search=ts_act_Maori+language_resel\&p=1\&sr=1

New Zealand Parliament (1989) Education Act 1989. Available at: http://www.legislation.govt.nz/ act/public/1989/0080/latest/versions.aspx?search=ts_act\%40bill\%40regulation\%40deemedreg education + act_resel_25_h\&p=1

Orange C (1987) The Treaty of Waitangi. Wellington, New Zealand: Allen and Unwin/Port Nicholson Press.

O'Sullivan D (2007) Beyond Biculturalism: The Politics of an Indigenous Minority. Wellington, New Zealand: Huia.

Pihama L, Reynolds P, Smith C, et al. (2014) Positioning historical trauma theory within Aotearoa New Zealand. AlterNative 10(3): 248-262.

Rameka L (2016) Kia whakatōmuri te haere whakamua: 'I walk backwards into the future with my eyes fixed on my past'. Contemporary Issues in Early Childhood 17(4): 387-398.

Ritchie JE (1992) Becoming Bicultural. Wellington, New Zealand: Huia.

Royal Commission on Social Policy (1987) The Treaty of Waitangi and social policy. Discussion booklet no. 1. Wellington, New Zealand: Royal Commission on Social Policy.

Royal Society of New Zealand (2013) Languages in Aotearoa New Zealand. Available at: https://royalsociety.org.nz/what-we-do/our-expert-advice/all-expert-advice-papers/languages-in-aotearoa-new-zealand/

Shaw S, Elston J and Abbott S (2004) Comparative analysis of health policy implementation: The use of documentary analysis. Policy Studies 25(4): 259-266.

Simon-Kumar R (2019) The multicultural dilemma: Amid rising diversity and unsettled equity issues, New Zealand seeks to address its past and present. Migration Information Source, 5 September. Available at: https://www.migrationpolicy.org/article/rising-diversity-and-unsettled-equity-issues-new-zealand

Spoonley P (2015) New diversity, old anxieties in New Zealand: The complex identity politics and engagement of a settler society. Ethnic and Racial Studies 38(4): 650-661.

Spoonley P and Bedford R (2012) Welcome to Our World? Immigration and the Reshaping of New Zealand. Auckland, New Zealand: Dunmore.

Statistics New Zealand (2014) 2013 Census QuickStats about culture and identity. Available at: http://archive. stats.govt.nz/Census/2013-census/profile-and-summary-reports/quickstats-culture-identity.aspx\#gsc. tab $=0$

Statistics New Zealand (2018) 2018 Census place summaries. Available at: https://www.stats.govt.nz/ tools/2018-census-place-summaries/

Statistics New Zealand (2019) New Zealand's population reflects growing diversity. Available at: https:// www.stats.govt.nz/news/new-zealands-population-reflects-growing-diversity

Vertovec S (2007) Super-diversity and its implications. Ethnic and Racial Studies 30(6): 1024-1054.

Vertovec S (2019) Talking around super-diversity. Ethnic and Racial Studies 42(1): 125-139.

Waitangi Tribunal (1986) Report of the Waitangi Tribunal on the Te Reo Maori Claim (Wai 11). Wellington, New Zealand: Government Printer.

Waitangi Tribunal (2014) He Whakaputanga me te Tiriti: The Declaration and the Treaty (Wai 1040), vol. 2. Wellington, New Zealand: Waitangi Tribunal. Available at: https://waitangitribunal.govt.nz/assets/ Documents/Publications/WT-Part-2-Report-on-stage-1-of-the-Te-Paparahi-o-Te-Raki-inquiry.pdf

Walker R (2004) Ka Whawhai Tonu Matou. Auckland, New Zealand: Penguin.

Walters L (2018) Fact check: Disparities between Māori and Pākehā. Stuff, 9 February. Available at: https:// www.stuff.co.nz/national/politics/101231280/fact-check-disparities-between-mori-and-pkeh 
Ward C and Liu JH (2012) Ethno-cultural conflict in Aotearoa/New Zealand: Balancing indigenous rights and multicultural responsibilities. In: Landis D and Albert R (eds) Handbook of Ethnic Conflict: International Perspectives. New York: Springer, pp. 45-69.

\section{Author biographies}

Angel Chan is a Senior Lecturer in the Faculty of Education and Social Work at the University of Auckland, New Zealand. Her research areas include early childhood education, culture and identity, sociology of childhood, transnational parenting, critical multicultural education and superdiversity in education settings.

Jenny Ritchie is an Associate Professor in the Te Puna Akopai School of Education at Te Herenga Waka Victoria University of Wellington, New Zealand. Her research and teaching focus on social, cultural and ecological justice in early childhood care and education. 